\title{
PENGUJIAN USABILITY DENGAN TEKNIK SYSTEM USABILITY SCALE PADA TEST ENGINE TRY OUT SERTIFIKASI
}

\author{
Suyanto ${ }^{1}$, Usman Ependi ${ }^{2}$ \\ ${ }^{1}$ Program Studi Sistem Informasi, Universitas Bina Darma \\ ${ }^{2}$ Program Studi Teknik Informatika, Universitas Bina Darma \\ Email: ${ }^{1}$ suyanto@binadarma.ac.id, ${ }^{2}$ u.ependi@binadarma.ac.id
}

\begin{abstract}
ABSTRAK
Test engine try out merupakah sistem informasi yang digunakan oleh mahasiswa calon alumni untuk melakukan uji coba atau latihan soal untuk mengikuti ujian sertifikasi yang ada di Universitas Bina Darma. Uji coba atau latihan yang dapat dilakukan pada test engine ini merupakan uji coba untuk sertifikasi vendor seperti "Microsoft Technology Associate, SAP, NIIT, PASAS, CISCO, dan berbagai sertifikasi laiinya”. Untuk memastikan apakah test engine ini telah sesuai dengan harapan dan kebtuhan peserta try out maka dilakukan evaluasi. Teknik evaluasi yang digunakan adalah usability dengan pendekatan system usability scale. System usability scale merupakan teknik evaluasi sistem informasi yang melihat tiga aspek yaitu adjective rating, grade scale, acceptability dilakukan dengan melibatkan pengguna akhir. Dalam proses evaluasi system usability scale digunakan sepuluh instrumen sebagai pengukur evaluasi. Dari evaluasi yang dilakukan didapat hasil akhir 87.33. Sesuai kondisi tersebut maka dapat dikatakan bahwa test engine try out dari sisi adjective rating termasuk kelompok excellence, dari sisi grade scale termasuk kelompok B, dan dari sisi acceptability termasuk kelompok acceptable.
\end{abstract}

Kata Kunci : Usability, System Usability Scale, Test Engine, Sertifikasi

\section{ABSTRACT}

Test engine try out is an information system used by prospective alumni students to practice the questions in taking the certification exams at Bina Darma University. Exercises that can be done on this test engine are vendor certifications such as Microsoft Technology Associate, SAP, NIIT, PASAS, CISCO, and various other certifications. To ascertain whether the test engine is in line with the expectations and needs of the participants try out then an evaluation is carried out. The evaluation technique used is usability with the system usability scale approach. System usability scale is an information system evaluation technique that looks at three aspects, namely adjective rating, grade scale, acceptability by involving end users in the evaluation process. In the process of evaluating the usability scale system, ten instruments were used as a measure of evaluation. From the evaluation, the final result is 87.33. According to these conditions, it can be concluded that the test engine try out from the side of the adjective rating includes the excellence group, from the grade scale side including $B$ group, and from the acceptability side including the acceptable group.

Keyword : Usability, System Usability Scale, Test Engin, Certification

Author Korespondensi (Usman Ependi)

Email : u.ependi@binadarma.ac.id

\section{PENDAHULUAN}

Dalam sebuah organisasi baik itu lembaga pendidikan, pemerintahan dan industri saat ini telah menggunakan dukungan teknologi informasi dan komunikasi (TIK). penggunaan TIK sendiri sebagai upaya untuk menigkatkan produktifitas dan kualitas dari sebuah layanan ataupun produk yang akan dihasilkan atau diberikan. Pada lembaga Pendidikan penggunaan TIK dapat dilihat dari adanya sistem informasi akademik mulai dari penerimaan siswa baru sampai dengan kelulusan atauh bahkan setelah lulus sekalipun. Pada lembaga Pendidikan terutama lembaga Pendidikan tinggi seperti Universitas hal yang paling mendasarkan yang harus dilakukan adalah menyiapkan atau menghasilkan sumber daya manusia yang berdaya saing sesuai kompetensi. Salah satu pendidikan tinggi yang ada yaitu Universitas Bina Darma, dimana saat 
ini telah menggunakan TIK sebagai tulang punggung kegiatan operasionalnya. Penggunaan TIK tersebut dapat dilihat operasional kegiatan tri dharma maupun kegiatan pendukung [1]. Kondisi tersebut dilakukan sebagai upaya peningkatan kompetensi lulusan yang akan dihasilkan.

Salah satu upaya nyata tersebut yaitu dapat dilihat dalam persiapan peningkatan kompetensi lulusan berupa sertifikasi vendor. dalam proses persiapan ujian tersebut dilakukan ujian percobaan melalui test engine try out. Test engine try out merupakah sistem informasi yang digunakan oleh mahasiswa calon alumni untuk melakukan uji coba atau latihan soal untuk mengikuti ujian sertifikasi yang ada di Universitas Bina Darma. Uji coba atau latihan yang dapat dilakukan pada test engine ini merupakan uji coba untuk sertifikasi vendor seperti "Microsoft Technology Associate, SAP, NIIT, PASAS, CISCO, dan berbagai sertifikasi laiinya" [2]. Peserta yang mengikuti latihan atau uji coba pada test engine try out ini merupakan mahasiswa calon lulusan.

Untuk itu memastikan apakah test engine try out yang disediakan telah memiliki nilai kebergunaan bagi mahasiswa calon lulusan maka perlu dilakukan pengukuran tingkat kebergunaan melalui evaluasi pandangan pengguna. Untuk melakukan evaluasi berdasarkan pandangan pengguna dapat digunakan teknik pengukuran usability, karena usability merupakan teknik pengukuran yang dilakukan sesuai dengan pengalaman pengguna terhadap sebuah sistem. Pengukuran dengan teknik usability berfokus pada penilaian tingkat kebergunaan sistem yang disediakan [3]. Pengukuran usability menjadi sangat penting mengingat usability mampu untuk menggambarkan apakah pengguna dapat menerima sistem yang dihasilkan atau tidak [4].

Dalam melakukan evaluasi dengan teknik usability dapat dilakukan dengan dua cara yaitu (1) yang melibatkan ahli dan (2) yang melibatkan pengguna dari sistem itu sendiri [5]. Objek yang menjadi sasaran evaluasi juga bervariasi baik sistem yang dijalankan berbasis web, desktop, maupun berbasis mobile [6]. Focus dari penilaian usability sebenarnya terdapat lima aspek yaitu yaitu: “(1) learnability, (2) efficiency, (3) memorability, (4) errors, dan (5) satisfaction" [7]. Dari kedua cara evaluasi usability teknik evaluasi yang dilakukan berdasarkan pandangan pengguna pengguna adalah teknik system usability scale [8]. System usability scale sendiri memiliki kelebihan yaitu: "(1) proses evaluasi lebih mudah dimengerti oleh responden, (2) dapat melibatkan sampel yang sedikit namun dapat menggambarkan hasil yang maksimal, dan (3) dapat membedakan dengan jelas antara aplikasi yang dapat dan tidak dapat digunakan" [9].

Pengukuran evaluasi berdasarkan pandangan pengguna dengan teknik system usability scale dilakukan dengan perhitungan yang jelas atau dengan kata lain memiliki teknik perhitungan sendiri. Dengan demikian hasil pengukuran dapat dipertanggungjawabkan [10]. Untuk itu sebagai langkah pemastian nilai kebergunaan terhadap test engine try out yang dihasilkan maka digunakan system usability scale sebagai teknik evaluasi pandangan pengguna. Dengan dilakukannya evaluasi pandangan pengguna dengan teknik system usability scale ini diharapkan menghasilkan gambaran perspektif pengguna terhadap test engine try out sehingga memudahkan jika akan dilakukan perbaikan atau hal terkait lainnya.

\section{METODOLOGI}

Untuk melakukan evaluasi berdasarkan pandangan pengguna terhadap test engine try out maka metode yang digunakan.

\subsection{Metode Penyajian}

Dalam melakukan evaluasi pandangan pengguna terhadap test engine try out menggunakan teknik system usability scale metode penyajian hasil peneltian digunakan metode deskriptif. Metode ini digunakan karena metode mengedepankan fakta atau penomena terhadap sebuah kejadian pada proses penelian. Metode ini juga mengedepankan presepsi peneliti dalam menjabarkan fakta dan penomena tesebut [11].

\subsection{Metode Pengumpulan Data}

Dalam proses penelitian metode pengumpulan data yang digunakan adalah menggunakan kuisioner. Kuisoner yang dibuat sesuai dengan teknik system usability scale seperti pada Tabel 1 . 


\subsection{Metode Pengukuran}

Untuk mengukur hasil perhitungan evaluasi persepektif pengguna terhadap test engine try out menggunakan teknik system usability system memiliki teknik tersendiri dengan membedakan antara instrumen yang bernomor ganjil dan bernomor genap. Instrumen pengukuran teknik system usability scale seperti yang diperlihatkan pada Tabel 1 .
Aturan perhitungan tesebut yaitu: “(1) Instrumen nomor ganjil skala jawaban dikurangi 1. (2) Instrumen nomor genap 5 dikurangi skala jawaban. (3) Skala 0 sampai dengan 4 (empat respon paling positif). (4) Menjumlahkan skala jawaban dan dikali 2.5. (5) Menentukan rerata jawaban instrumen" [12].

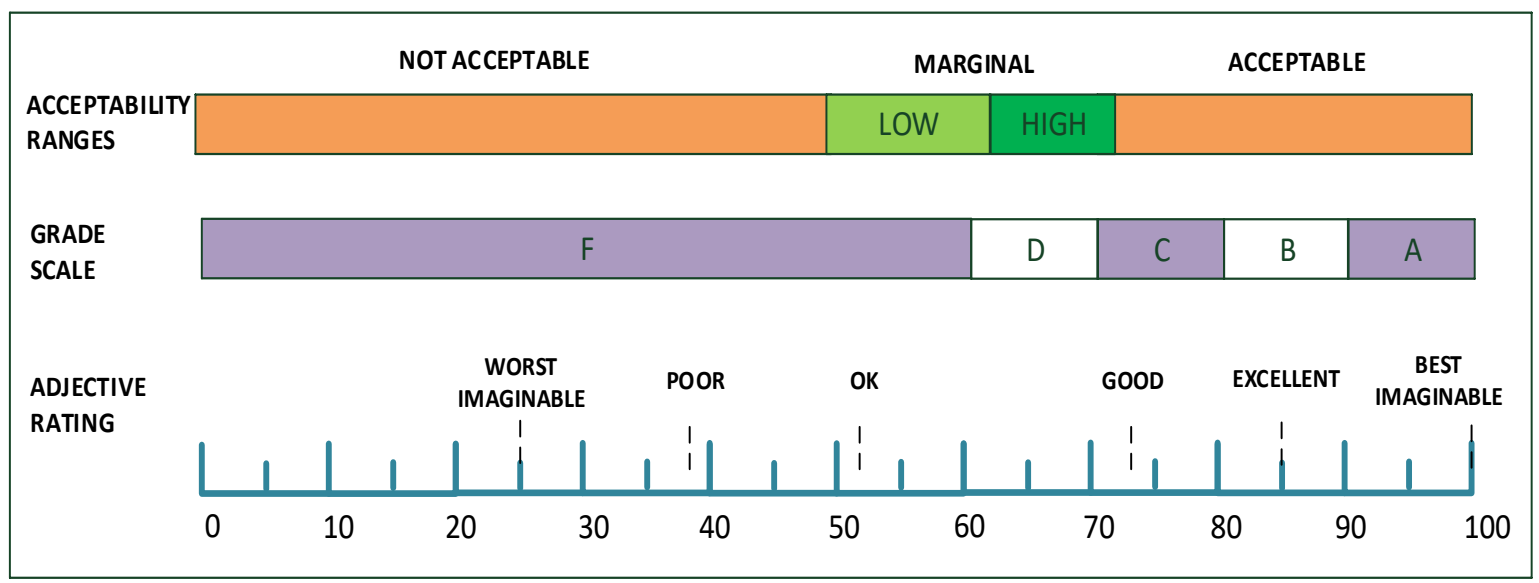

Gambar 1. Penentuan Hasil Penilaian [13]

Serelah diketahui nilai untuk masingmasing instrumen sesuai dengan ketentuan perhitungan system usability scale maka untuk menentukan hasil apakah test engine try out dapat dikategorikan memiliki nilai kebergunaan atau tidak maka dapat dilakukan dengan mencocokan nilai hasil evaluasi persepektif pengguna dengan ketentuan pemberian nilai akhir system usability scale seperti yang diperlihatkan pada Gambar 1.

Tabel 1. System Usability Scale Instrumen

\begin{tabular}{|c|c|c|}
\hline No & Petanyaan & Skala \\
\hline 1 & $\begin{array}{l}\text { I think that I would like to use } \\
\text { this system frequently } \\
\text { (Saya pikir bahwa saya akan } \\
\text { ingn lebih sering menggunakan } \\
\text { aplikasi ini) }\end{array}$ & $1-5$ \\
\hline 2 & $\begin{array}{l}\text { I found the system unnecessarily } \\
\text { complex. } \\
\text { (Saya meemukan bahwa } \\
\text { aplikasi ini, tidak harus dibuat } \\
\text { serumit ini) }\end{array}$ & $1-5$ \\
\hline 3 & $\begin{array}{l}\text { I thought the system was easy to } \\
\text { use } \\
\text { (Saya pikir aplikasi mudah }\end{array}$ & $1-5$ \\
\hline
\end{tabular}

\begin{tabular}{|l|l|c|}
\hline & untuk digunakan) & \\
\hline 4 & $\begin{array}{l}\text { I think that I would need the } \\
\text { support of a technical person to } \\
\text { be able to use this system (Saya } \\
\text { pikir bahwa saya akan } \\
\text { membutuhkan bantuan dari } \\
\text { orang teknis untuk dapat } \\
\text { menggunakan aplikasi ini) }\end{array}$ & \\
\hline 5 & $\begin{array}{l}\text { I found the various functions in } \\
\text { this system were well integrated } \\
\text { (Saya menemukan berbagai } \\
\text { fungsi di aplikasi ini } \\
\text { diintegrasikan dengan baik) }\end{array}$ & $1-5$ \\
\hline 6 & $\begin{array}{l}\text { I thought there was too much } \\
\text { inconsistency in this system } \\
\text { (Saya pikir ada terlalu banyak } \\
\text { ketidakkonsistenan dalam } \\
\text { aplikasi ini) }\end{array}$ & $1-5$ \\
\hline 7 & $\begin{array}{l}\text { I would imagine that most } \\
\text { people would learn to use this } \\
\text { system very quickly } \\
\text { (Saya bayangkan bahwa } \\
\text { kebanyakan orang akan mudah } \\
\text { untuk mempelajari aplikasi ini } \\
\text { dengan sangat cepat) }\end{array}$ & \\
\hline 8 & $\begin{array}{l}\text { I found the system very } \\
\text { cumbersome to use }\end{array}$ & $1-5$ \\
\hline
\end{tabular}




\begin{tabular}{|c|c|c|}
\hline & $\begin{array}{l}\text { (Saya menemukan, aplikasi ini } \\
\text { sangat rumit untuk digunakan) }\end{array}$ & \\
\hline 9 & $\begin{array}{l}\text { I felt very confident using the } \\
\text { system } \\
\text { (Saya merasa sangat percaya } \\
\text { diri untuk menggunakan } \\
\text { aplikasi ini) }\end{array}$ & $1-5$ \\
\hline 10 & $\begin{array}{l}\text { I needed to learn a lot of things } \\
\text { before I could get going with } \\
\text { this system } \\
\text { (Saya perlu belajar banyak hal } \\
\text { sebelum saya bisa memulai } \\
\text { menggunakan aplikasi) }\end{array}$ & $1-5$ \\
\hline
\end{tabular}

\subsection{Objek Pengukuran}

Evaluasi perspektif pengguna ini dilakukan terhadap test engine try out sertifikasi. Pada test engine try out terdapat dua jenis pengguna yaitu administrator dan peserta try out seperti yang diperlihatkan pada Gambar 2. Administrator bertugas sebagai pengelola data try out yang meliputi "(1) pengelolaan bank soal untuk sebagai instrumen ketika melakukan try out. (2) pengelolaan jadwal, kelas, waktu atau durasi try out sertifikasi. (3) pengelolaan data master seperti mata uji, peserta, kelas, nilai try out".
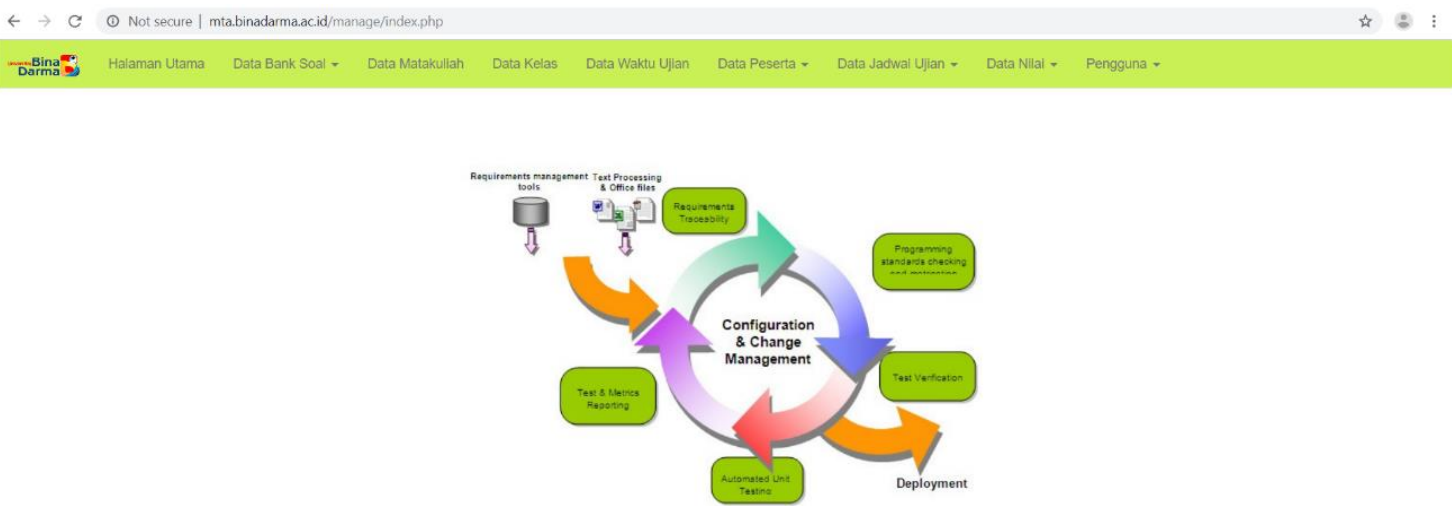

\section{Created By DSTI TIM $\odot$ copyright 2019 Universitas Bina Darma}

Gambar 2. Tampilan Halaman Administrator

Pengguna dengan akses seabgai peserta merupakan akses yang hanya dapat melakukan try out saja. Dimana waktu, jumlah soal dan mata uji ditentukan oleh administrator. Dalam melakukan try out peserta hanya perlu menjawab satu jawaban untuk setiap pertanyaan. Peserta juga diharus memperhatikan bobot pertanyaan karena setiap pertanyaan memiliki bobot yang berbeda. Kondisi tersebut dilakukan sesuai dengan kondisi nyata ketika peserta melakukan ujian sertifikasi. Setelah peserta melakukan try out atau waktu habis maka secara otomatis nilai hasil try out akan langsung diperlihatkan. Proses try out yang dilakukan peserta seperti yang diperlihatkan pada Gambar 3.

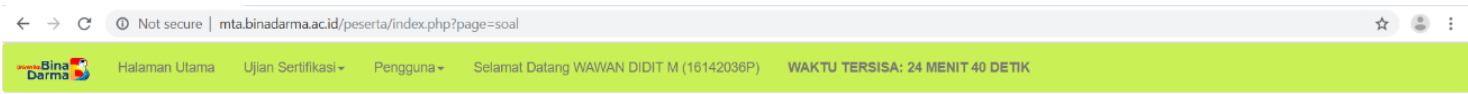

SOAL UJIAN MTA-SDF

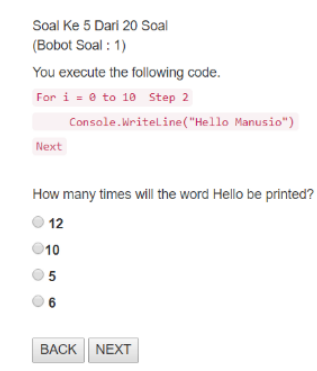




\section{Gambar 3. Proses Try Out}

\section{HASIL DAN PEMBAHASAN}

Sesuai metodologi penelitian yang telah dijelaskan sebelumnya maka dapat dijelaskan hasil penelitian sebagai berikut.

\subsection{Evaluator (Responden)}

Evaluasi perspektif pengguna terhadap test engine try out yang menjadi populasi yaitu semua mahasiswa yang melakukan ujian sertifikasi "Microsoft Technology Associate, SAP, NIIT, PASAS, CISCO, dan berbagai sertifikasi laiinya". Penentuan sampel untuk dijadikan responden di dalam teknik evaluasi system usability scale untuk menentukan jumlah responden terdapat ketentuan yang harus diikuti. System usability scale merupakan bagian yang tak terpisahkan dari konsep usability yaitu semakin kecil jumlah responden sebagai penilai maka semakin baik pula hasil evaluasi yang didapat. Kondisi tersebut terjadi pada evaluasi sistem informasi kepegawaian Dinas Petanian Bandung yang dilakukan dengan jumlah responden yaitu sepuluuh orang [14]. Pada evaluasi dengan teknik system usability scale pada kasus lain juga dilakukan dengan jumlah resonden sebanyak dua puluh responden yaitu ketika melakukan evaluasi aplikasi Palembang Guide [13]. Gambar 4 dapat dilihat bagaimana ilustrasi dalam penentuan responden dalam melakukan evaluasi.

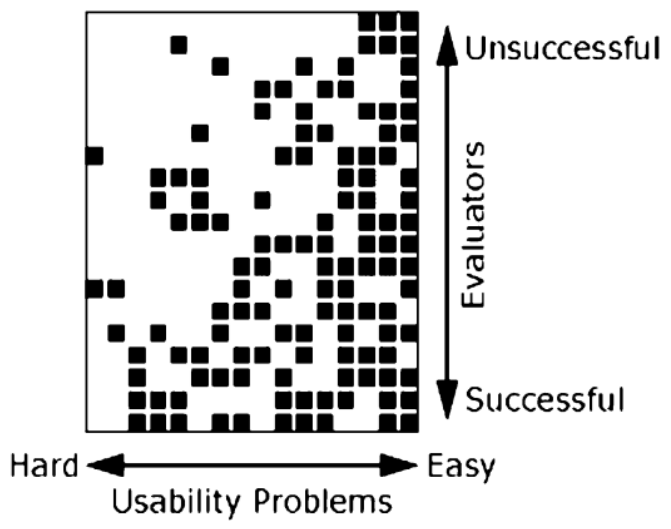

Gambar 4. Ilustrasi jumlah evaluator (Reponden) [15]

Dari Gambar 4 dapat dilihat bahwa dalam melakukan evaluasi usability jumlah responden menjadi sangat penting. Kondisi tersebut disebabkan jumlah responden yang sedikit akan berdampak semakin besarnya peluang untuk menemukan permasalahan pada objek uji yang dalam hal ini test engine try out. Kondisi tersebut juga akan terjadi pada hal sebaliknya. Dengan demikian didalam melakukan Evaluasi perspektif pengguna pada test engine try out ditentukan jumlah responden yaitu sebanyak lima belas responden. Penentuan jumlah lima belas responden dilakukan sebagai jalan tengah atas kajian yang telah dilakukan yaitu sebanyak sepuluh responden dan dua puluh responen. Untuk itu karateristik responden dalam melakukan evaluasi terdiri dari jenis kelamin dan program studi. Gambar 5 dapat diketahui merupakan karateristik responden evaluasi test engine try out. Dimana responden dengan jenis kelamin laki-laki sebesar $70 \%$ atau setara dengan 17 responden sedangkan jenis kelamin perempuan sebesar $30 \%$ atau setara dengan 6 responden.

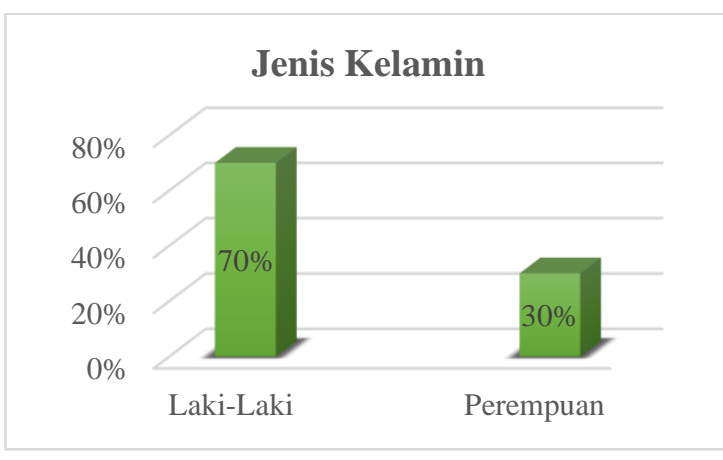

Gambar 5. Karateristik Jenis Kelamin

Selain karateristik responden yang dilihat dari jenis kelamin seperti yang diperlihatkan pada Gambar 5 maka karateristik lain yaitu program studi. Pada Gambar 6 dapat dilihat merupakan karateristik responden untuk program studi. Dalam melakukan evaluasi test engine try out terdapat dua program studi yang menjadi yang dilibatkan yaitu program studi sistem informasi dan program studi teknik informasi. dapat diketahui sesuai Gambar 6 bahwa responden dengan program studi teknik informatika menjadi responden yang dominan yaitu sebesar $65 \%$ sedangkan pada pgroam studi sistem informasi hanya $35 \%$. 


\section{Program Studi}

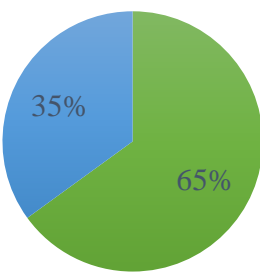

- Sistem Informasi $\quad$ Teknik Informatika

Gambar 6. Karateristik Program Studi

\subsection{Hasil Evaluasi}

Berdasarkan hasil kuisioner yang diberikan kepada responden yaitu peserta yang telah mengikuti try out menggunakan test engine try out sertifikasi maka hasil rekapitulasi jawaban responden seperti pada Tabel 2. Kuisioner yang diberikan kepada responden berdasarkan instrumen system usability scale seperti yang diperlihatkan pada Tabel 1. Skala jawaban yang digunakan yaitu dari 1 sampai dengan 5, dimana 5 menyatakan sangat setuju dengan pernyataan instrumen dan 1 menyatakan sangat tidak setuju dengan pernyataan instrument.

Tabel 2. Jawaban Responden

\begin{tabular}{|l|l|l|l|l|l|l|l|l|l|l|}
\hline & P1 & P2 & P3 & P4 & P5 & P6 & P7 & P8 & P9 & P10 \\
\hline R1 & 5 & 2 & 5 & 2 & 5 & 2 & 5 & 2 & 4 & 1 \\
\hline R2 & 4 & 2 & 5 & 1 & 4 & 2 & 5 & 1 & 5 & 2 \\
\hline R3 & 5 & 1 & 5 & 1 & 4 & 2 & 5 & 2 & 5 & 1 \\
\hline R4 & 5 & 1 & 5 & 1 & 4 & 2 & 4 & 2 & 5 & 1 \\
\hline R5 & 5 & 2 & 4 & 1 & 4 & 2 & 5 & 2 & 5 & 2 \\
\hline R6 & 5 & 2 & 4 & 1 & 4 & 1 & 5 & 1 & 5 & 1 \\
\hline R7 & 4 & 2 & 4 & 1 & 5 & 2 & 5 & 2 & 5 & 2 \\
\hline R8 & 5 & 1 & 4 & 2 & 5 & 2 & 5 & 2 & 5 & 2 \\
\hline R9 & 5 & 1 & 5 & 2 & 4 & 2 & 5 & 1 & 4 & 2 \\
\hline R10 & 5 & 1 & 4 & 2 & 4 & 2 & 5 & 2 & 5 & 2 \\
\hline R11 & 5 & 1 & 5 & 2 & 4 & 2 & 5 & 1 & 4 & 2 \\
\hline R12 & 4 & 2 & 4 & 1 & 4 & 2 & 4 & 2 & 5 & 2 \\
\hline R13 & 5 & 1 & 4 & 1 & 4 & 2 & 4 & 1 & 5 & 2 \\
\hline R14 & 5 & 1 & 5 & 1 & 4 & 2 & 5 & 2 & 5 & 2 \\
\hline R15 & 4 & 1 & 4 & 2 & 4 & 1 & 4 & 1 & 5 & 2 \\
\hline
\end{tabular}

Jawaban responden seperti yang pada Tabel 2 merupakan jawaban responden yang belum dilakukan perhitungan sesuai dengan teknik pengukuran dengan system usability scale. Untuk itu dari jawaban pada Tabel 2 dilakukan perhitungan untuk langkah-langkah perhitungan system usability scale "(1) Instrumen nomor ganjil skala jawaban dikurangi 1. (2) Instrumen nomor genap 5 dikurangi skala jawaban. (3) Skala 0 sampai dengan 4 (empat respon paling positif)". Dari ketentuan 1,2 dan 3 maka hasil konversi atau perhitungan seperti yang diperlihatkan pada Tabel 3. Pada Tabel 2 dan Tabel 3 merupakan hasil jawaban awal dan hasil jawaban yang telah dilakukan perhitungan. Dimana kolom P mengindikasikan sebagai pernyataan dan $\mathrm{R}$ sebagai responden.

Tabel 3. Pehitungan Jawaban Responden

\begin{tabular}{|l|l|l|l|l|l|l|l|l|l|l|l|}
\hline & P1 & P2 & P3 & P4 & P5 & P6 & P7 & P8 & P9 & P10 & $\Sigma$ \\
\hline R1 & 4 & 3 & 4 & 3 & 4 & 3 & 4 & 3 & 3 & 4 & 35 \\
\hline R2 & 3 & 3 & 4 & 4 & 3 & 3 & 4 & 4 & 4 & 3 & 35 \\
\hline R3 & 4 & 4 & 4 & 4 & 3 & 3 & 4 & 3 & 4 & 4 & 37 \\
\hline R4 & 4 & 4 & 4 & 4 & 3 & 3 & 3 & 3 & 4 & 4 & 36 \\
\hline R5 & 4 & 3 & 3 & 4 & 3 & 3 & 4 & 3 & 4 & 3 & 34 \\
\hline R6 & 4 & 3 & 3 & 4 & 3 & 4 & 4 & 4 & 4 & 4 & 37 \\
\hline R7 & 3 & 3 & 3 & 4 & 4 & 3 & 4 & 3 & 4 & 3 & 34 \\
\hline R8 & 4 & 4 & 3 & 3 & 4 & 3 & 4 & 3 & 4 & 3 & 35 \\
\hline R9 & 4 & 4 & 4 & 3 & 3 & 3 & 4 & 4 & 3 & 3 & 35 \\
\hline R10 & 4 & 4 & 3 & 3 & 3 & 3 & 4 & 3 & 4 & 3 & 34 \\
\hline R11 & 4 & 4 & 4 & 3 & 3 & 3 & 4 & 4 & 3 & 3 & 35 \\
\hline R12 & 3 & 3 & 3 & 4 & 3 & 3 & 3 & 3 & 4 & 3 & 32 \\
\hline R13 & 4 & 4 & 3 & 4 & 3 & 3 & 3 & 4 & 4 & 3 & 35 \\
\hline R14 & 4 & 4 & 4 & 4 & 3 & 3 & 4 & 3 & 4 & 3 & 36 \\
\hline R15 & 3 & 4 & 3 & 3 & 3 & 4 & 3 & 4 & 4 & 3 & 34 \\
\hline
\end{tabular}

Hasil perhitungan jawaban responden seperti yang diperlihatkan pada Tabel 3 merupakan hasil proses yang dilakukan pada tahapan 1,2 dan 3. Namun pada Tabel 3 juga dilakukan penjulahan terhadap masing-masing jawaban responden untuk menentukan nilai rerata jawaban responden agar mendapatkan nilai akhir evaluasi sesuai kententuan system usability scale pada tahapan "(4) Menjumlahkan skala jawaban dan dikali 2.5. 
dan (5) Menentukan rerata jawaban instrumen". Proses pada tahapan 4 dan 5 merupakan tahapan akhir untuk menentukan hasil evaluasi. Pada Tabel dapat dilihat proses perkalian untuk setiap jawaban responden dikali 2.5 dan selanjutnya ditentukan jumlah rata-rata sebagai hasil akhir.

Tabel 4. Penentuan Nilai Akhir

\begin{tabular}{|l|c|c|}
\hline & $\sum$ Rerta $* 2.5$ & Jumlah \\
\hline $\mathrm{R} 1$ & $35 * 2.5$ & 87.5 \\
\hline $\mathrm{R} 2$ & $35 * 2.5$ & 87.5 \\
\hline $\mathrm{R} 3$ & $37 * 2.5$ & 92.5 \\
\hline $\mathrm{R} 4$ & $36 * 2.5$ & 90 \\
\hline $\mathrm{R} 5$ & $34 * 2.5$ & 85 \\
\hline $\mathrm{R} 6$ & $37 * 2.5$ & 92.5 \\
\hline $\mathrm{R} 7$ & $34 * 2.5$ & 85 \\
\hline $\mathrm{R} 8$ & $35 * 2.5$ & 87.5 \\
\hline $\mathrm{R} 9$ & $35 * 2.5$ & 87.5 \\
\hline $\mathrm{R} 10$ & $34 * 2.5$ & 85 \\
\hline $\mathrm{R} 11$ & $35 * 2.5$ & 87.5 \\
\hline $\mathrm{R} 12$ & $32 * 2.5$ & 80 \\
\hline $\mathrm{R} 13$ & $35 * 2.5$ & 87.5 \\
\hline $\mathrm{R} 14$ & $36 * 2.5$ & 90 \\
\hline $\mathrm{R} 15$ & $34 * 2.5$ & 85 \\
\hline Nilai Rata-Rata & $1310 / 15=\mathbf{8 7 . 3 3}$ \\
\hline
\end{tabular}

Hasil evaluasi seperti pada Tabel 4 dapat diketahui yaitu 87.33. untuk mendapatkan bagaimana perspektif pengguna maka hasil akhir dicocokkan sesuai ketentuan seperti yang diperlihatkan pada Gambar 1. Sesuai kondisi tersebut maka dapat dikatakan bahwa test engine try out dari sisi adjective rating termasuk kelompok excellence, dari sisi grade scale termasuk kelompok $\mathrm{B}$, dan dari sisi acceptability termasuk kelompok acceptable. Sesuai dengan kondisi tersebut maka pengguna berpandangan test engine try out memiliki nilai kebergunaan yang baik serta dapat digunakan secara berkelanjutan.

\section{SIMPULAN DAN SARAN}

Dari uraian yang telah dikemukakan dalam melakukan evaluasi perspektif pengguna dalam menggunakan test engine try out maka dapat disimpulkan bahwa pengguna berpandangan test engine yang digunakan telah sesuai yang dibuktikan dari acceptability termasuk kelompok acceptable. Test engine juga saat ini belum membutuhkan perbaikan yang memadai yang dibuktikan dari grade scale termasuk kelompok B. Test engine juga mendapatkan sambutan yang baik dari para peserta yang dibuktikan dari nilai adjective rating termasuk kelompok excellence. Walaupun test engine tidak memiliki masalah usability berdasarkan tiga kategori system usability scale penulis menyarankan bagi peneliti lain untuk melakukan pengujian ulang dimasa yang akan datang mengingat kondisi dan waktu yang berbdea serta teknologi tertunya juga berubah. Sehinga akan mempengaruhi pandangan pengguna.

\section{UCAPAN TERIMA KASIH}

Ucapan terima kasih yang setingitingginya kami sampaikan kepada Universitas Bina Darma yang telah membiayai penelitian ini. terima kasih yang tak terhingga juga disampaikan kepada Tim Redaksi Jurnal MATRIK Universitas Bumigora Mataram yang bersedia melakukan review dan mempublikasi artikel ini.

\section{REFERENSI}

[1] A. Syazili, F. Fatoni, and R. Sutejo, "Pemodelan dan Implementasi Perangkat Lunak Berbasis Mobile pada Bina Darma TV," JISKA (Jurnal Informatika Sunan Kalijaga), vol. 3, no. 3, pp. 62-69, 2019.

[2] S. Sauda, N. Oktaviani, and M. Bunyamin, "Implementasi Metode Scrum Dalam Pengembangan Test Engine Try Out Sertifikasi," JISKA (Jurnal Informatika Sunan Kalijaga), vol. 3, no. 3, pp. 70-78, 2019.

[3] J. Nielsen. (2012, June 7, 2018). Usability 101: Introduction to Usability. Available: https://www.nngroup.com/articles/usabil ity-101-introduction-to-usability/

[4] Y. Nurhadryani, S. K. Sianturi, I. Hermadi, and H. Khotimah, "Pengujian usability untuk meningkatkan antarmuka aplikasi mobile," Jurnal Ilmu Komputer 
dan Agri-Informatika, vol. 2, no. 2, 2013.

[5] E. Susilo, B. S. WA, and H. Al Fatta, "Evaluasi Aplikasi Mobile SSP (Secure System of Payment) Menggunakan Prinsip Usability," Semnasteknomedia, vol. 5, no. 1, pp. 2-6-7, 2017.

[6] B. Pudjoatmodjo and R. Wijaya, "Tes Kegunaan (Usabilty Testing) Pada Aplikasi Kepegawaian Dengan Menggunakan System Usabilty Scale (Studi Kasus: Dinas Pertanian Kabupaten Bandung)," Semnasteknomedia, vol. 4 , no. 1, pp. 29-37, 2016.

[7] T. Xie, H. Chen, J. Li, and H. Xiong, "A study on the methods of software testing based on the design models," in Computer Science \& Education (ICCSE), 2011 6th International Conference on, 2011, pp. 111-113: IEEE.

[8] W. U. Martoyo and F. Suprapto, "Kajian Evaluasi Usability dan Utility pada Situs Web," SESINDO 2015, vol. 2015, 2015.

[9] Usability.gov. (2018, June 29). System Usability Scale (SUS). Available: https://www.usability.gov/how-to-andtools/methods/system-usabilityscale.html

[10] J. Sauro. (2011, November 28). Measuring Usability With The System
Usability Scale (SUS). Available: https://measuringu.com/sus/

[11] M. K. Nasution, "Penggunaan Metode Pembelajaran Dalam Peningkatan Hasil Belajar Siswa," Jurnal Studia Didaktika, vol. 11, no. 01, pp. 9-16, 2018.

[12] U. Ependi, A. Putra, and F. Panjaitan, "Evaluasi tingkat kebergunaan aplikasi Administrasi Penduduk menggunakan teknik System Usability Scale," Register: Jurnal Ilmiah Teknologi Sistem Informasi, vol. 5, no. 1, pp. 6376, 2019.

[13] U. Ependi, F. Panjaitan, and $H$. Hutrianto, "System Usability Scale Antarmuka Palembang Guide Sebagai Media Pendukung Asian Games XVIII," Journal of Information Systems Engineering and Business Intelligence, vol. 3, no. 2, pp. 80-86, 2017.

[14] B. Pudjoatmodjo and R. Wijaya, "Tes Kegunaan (Usabilty Testing) Pada Aplikasi Kepegawaian Dengan Menggunakan System Usabilty Scale (Studi Kasus: Dinas Pertanian Kabupaten Bandung)," SEMNASTEKNOMEDIA ONLINE, vol. 4, no. 1, pp. 2-9-37, 2016.

[15] M. Tory and T. Moller, "Evaluating visualizations: do expert reviews work?," IEEE computer graphics applications, vol. 25 , no. 5, pp. 8-11, 2005. 